\title{
Compensatory growth in an aquatic plant mediates exploitative competition between seasonally tied herbivores
}

\author{
Bert Hidding, ${ }^{1}$ Bart A. Nolet, Thiss de Boer, Peter P. de Vries, and Marcel Klaassen \\ Department of Plant-Animal Interactions, Centre for Limnology, Netherlands Institute of Ecology, Rijksstraatweg 6, \\ 3631 AC Nieuwersluis, The Netherlands
}

\begin{abstract}
The degree to which vertebrate herbivores exploitatively compete for the same food plant may depend on the level of compensatory plant growth. Such compensation is higher when there is reduced density-dependent competition in plants after herbivore damage. Whether there is relief from competition may largely be determined by the life-history stage of plants under herbivory. Such stage-specific compensation may apply to seasonal herbivory on the clonal aquatic plant sago pondweed (Potamogeton pectinatus L.). It winters in sediments of shallow lakes as tubers that are foraged upon by Bewick's Swans (Cygnus columbianus bewickii Yarrell), whereas aboveground biomass in summer is mostly consumed by ducks, coots, and Mute Swans. Here, tuber predation may be compensated due to diminished negative density dependence in the next growth season. However, we expected lower compensation to summer herbivory by waterfowl and fish as density of aboveground biomass in summer is closely related to photosynthetic carbon fixation. In a factorial exclosure study we simultaneously investigated (1) the effect of summer herbivory on aboveground biomass and autumn tuber biomass and (2) the effect of tuber predation in autumn on aboveground biomass and tuber biomass a year later. Summer herbivory strongly influenced belowground tuber biomass in autumn, limiting food availability to Bewick's Swans. In contrast, tuber predation in autumn by Bewick's Swans had a limited and variable effect on P. pectinatus biomass in the following growth season. Whereas relief from negative density dependence largely eliminates effects of belowground herbivory by swans, aboveground herbivory in summer limits both above- and belowground plant biomass. Hence, there was an asymmetry in exploitative competition, with herbivores in summer reducing food availability for belowground herbivores in autumn, but not the other way around.
\end{abstract}

Key words: above- and belowground herbivory; aquatic macrophytes; Bewick's Swan; compensation; Cygnus columbianus bewickii; exploitative competition; herbivore tolerance; Potamogeton pectinatus; sago pondweed; sequential density dependence; The Netherlands; waterfowl.

\section{INTRODUCTION}

It is a well-established notion that many plant species are able to tolerate substantial levels of herbivore damage without enduring a proportional loss of fitness (Rosenthal and Kotanen 1994). The degree of tolerance observed is known as compensation (Strauss and Agrawal 1999), ranging from undercompensation in case herbivore damage is not fully overcome (see Belsky 1986) to overcompensation (Cargill and Jefferies 1984, McNaughton 1985, Paige and Whitham 1987) when plants even increase fitness parameters compared to undamaged controls. The consequence of compensation may be that competition between herbivore species may diminish, even to the extent that herbivores facilitate one another (McNaughton 1976, Arsenault and Owen-Smith 2002).

The level of herbivore tolerance in plants is far from fixed. It critically depends on factors such as the availability of resources (Maschinski and Whitham

Manuscript received 27 June 2008; revised 9 October 2008; accepted 14 October 2008. Corresponding Editor: T. J. Valone.

${ }^{1}$ E-mail: bertbiker@hotmail.com
1989, Häsler et al. 2008), the type of tissue consumed (Inouye 1982, Hjältén et al. 1993), and the timing of herbivory (Maschinski and Whitham 1989, Boege 2005, Barton 2008). Apart from intrinsic ontogenetic changes in tolerance, the intensity of competition in plants may also vary over time. In fact, density-biomass relationships (Yoda et al. 1963, Harper and White 1974) indicate that herbivores may reduce competition when there is strong negative density dependence. Such herbivore-induced relief may even cause overcompensation when density dependence is sequential (sensu Åström et al. 1996), as in the case of seasonality (i.e., Kot and Schaffer 1984, Kokko and Lindström 1998, Jonzén et al. 2002, Ratikainen et al. 2008). Sequential density dependence is a periodic change in the strength of population regulation in which alterations in population density at one particular life-history stage affect production in the following stage. Timing of herbivory may determine to what extent plants experience densitydependent mortality and hence compensation. The degree of compensation in turn affects future resource availability to herbivores. 
Differential compensation through sequential density dependence may be ubiquitous in seasonal ecosystems in which herbivory often is episodic. However, to our knowledge, the consequences of sequential density dependence from the perspective of the herbivore community have thus far received little scrutiny. Sequential density dependence was suggested to be a driver of compensation for the aquatic plant sago pondweed Potamogeton pectinatus L. (Jonzén et al. 2002, Ratikainen et al. 2008) that dominates the submersed vegetation in many temperate eutrophic lakes (van Wijk 1988). Its belowground tubers may experience heavy predation by migrating swans at stopover sites (Beekman et al. 1991, Nolet et al. 2001, LaMontagne et al. 2003). Nevertheless, this tuber predation is unlikely to directly cause the death of individual genets, which may be spread over considerable distance within a lake (Hangelbroek et al. 2002). In contrast, at the shallow lake Lauwersmeer in the Netherlands, moderate tuber predation by Bewick's Swans (Cygnus columbianus bewickii Yarrell) in autumn was overcompensated, returning a slightly higher yield of tubers the following year than low predation (Nolet 2004). Higher mortality due to tuber predation may lead to decreased self-thinning during the consecutive growth phase (Jonzén et al. 2002). If indeed autumn tuber predation does not have a negative effect on aboveground biomass in the following summer, Bewick's Swans do not compete with herbivores that utilize aboveground biomass of the same $P$. pectinatus-dominated macrophyte stands in summer.

These summer herbivores, most notably ducks, coots, and Mute Swans, forage on the aboveground tissues of sago pondweed (Anderson and Low 1976, van Wijk 1988, Søndergaard et al. 1996). Also, omnivorous fish may consume significant amounts of the plants (Prejs 1984, Körner and Dugdale 2003, Hilt 2006). On the one hand, plants may compensate for grazing on stems and leaves to some extent, as self-shading within the vegetation is accordingly reduced (Strauss and Agrawal 1999). On the other hand, consumption of aboveground tissues may directly hamper the plant's photosynthetic potential. Moreover, the removal of aquatic macrophyte shoots in a shallow lake may increase negative effects on the remaining plants. Aquatic plants can function as ecosystem engineers (Bouma et al. 2005), as they facilitate plant growth by decreasing wave action and increasing sedimentation. This positive feedback acts in the opposite direction as well, as vegetation loss may increase the remaining plant cover's exposure to wave action. Hence, a reduction in plant cover due to herbivory may lead to a larger impact of wave action and reduce plant cover even further (Jupp and Spence 1977, Schutten et al. 2005).

In this paper we investigate the mutual effects of aboveground herbivory in summer and belowground herbivory by Bewick's Swans in autumn. We conducted a factorial exclosure study separating aboveground from belowground herbivory. We measured aboveground biomass at three intervals in summer and belowground biomass outside the growing season before the arrival of migratory Bewick's Swans as well as after their departure. We hypothesized that $P$. pectinatus would largely compensate for tuber predation by Bewick's Swans over the growing season due to a release from negative density dependence effective in spring. On the other hand, we expected that foraging on aboveground biomass in summer by coots, ducks, Mute Swans, and large fish would inhibit plants from compensating for the losses by limiting the amount of carbon fixed and stored in tubers.

\section{Methods \\ Study system and site}

Exclosure experiments were carried out in the "Babbelaar," a branch of the shallow lake Lauwersmeer in The Netherlands (2100 ha; 5322' N, 06 $13^{\prime} \mathrm{E}$ ). The lake is eutrophic to hypertrophic, with a mean concentration of total nitrogen $(\mathrm{N})$ of $3.4 \mathrm{mg} / \mathrm{L}$ and total phosphorus $(\mathrm{P})$ of $0.28 \mathrm{mg} / \mathrm{L}$ (mean of monthly measurements from October 2003 to October 2007 covering the experimental period; data provided by the water board "Noorderzijlvest"). The Lauwersmeer is a former bay of the Wadden Sea that turned into a freshwater lake after its embankment in 1969. From the early 1970 s onward the lake became gradually colonized by sago pondweed (Potamogeton pectinatus L.). At the time the reported study started, sago pondweed could be found along the whole Lauwersmeer shoreline. The species dominates the vegetation composition of the "Babbelaar," where two other submersed macrophyte species are present: subordinate lesser pondweed (Potamogeton pusillus L.) and rare shoots of horned pondweed (Zannichellia palustris L.) (B. Hidding, B. A. Nolet, T. de Boer, P. P. de Vries, M. Klaassen, unpublished manuscript).

Since the mid-1970s high numbers of Bewick's Swans annually visit the lake on their autumn migration (Prop and van Eerden 1981). The birds usually arrive in the Lauwersmeer area in October and forage on the tubers of sago pondweed (Beekman et al. 1991, Nolet et al. 2001). The total time spent on tuber foraging in the Lauwersmeer is typically short, as after two to four weeks of massive swan presence numbers quickly drop as a fixed giving-up density of pondweed tubers is then attained (Nolet et al. 2002, 2006a). In the autumns (2003-2006) preceding aboveground sampling in summer, 4000, 5500, 2800, and 1200 swan-days (swan days are the sum of daily swan counts) were recorded in the Babbelaar, respectively (Nolet et al. 2006b; A. Gyimesi and B. A. Nolet, unpublished data) (see also Fig. 1). Aside from mortality through predation by swans, there is winter mortality of tubers of $\sim 15 \%$ (Santamaría and Rodríguez-Gironés 2002).

In summer, the macrophyte beds in the Lauwersmeer are exploited mainly by Eurasian Coots (Fulica atra L.), 


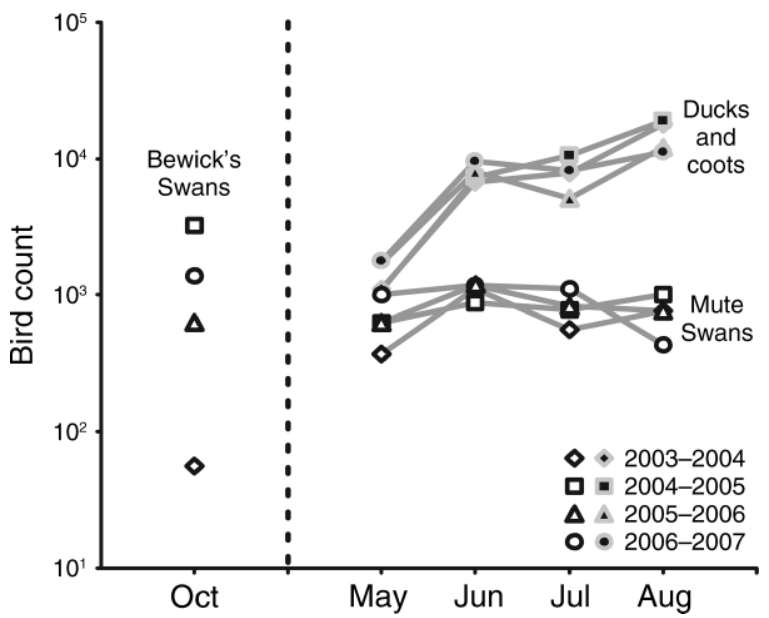

FIG. 1. Relevant bird counts in the Lauwersmeer in The Netherlands (one per month) for Bewick's Swans in October and for ducks, coots, and Mute Swans (Cygnus olor Gmelin) in the summer season. Counts once per month lack precision in the case of Bewick's Swans, since their presence only stretches for a few weeks. The category "Ducks and coots" is composed of Eurasian Coots (Fulica atra L.), Mallards (Anas platyrhynchos L.), Gadwalls (Anas strepera L.), and Green-winged Teals (Anas crecca L.). Mute Swans are indicated separately as their mass differs by more than an order of magnitude. The data are from Staatsbosbeheer (Dutch Forestry Service), Driebergen, The Netherlands.

Mallards (Anas platyrhynchos L.), Gadwalls (Anas strepera L.), Green-winged Teals (Anas crecca L.), and Mute Swans (Cygnus olor Gmelin). During the study period, each year numbers of ducks and coots increased from May to August in a similar way (Fig. 1). From approximately 1200 coots and ducks in May numbers steadily increased to \pm 17000 in August. Mute Swan numbers were more stable over these months, fluctuating between 400 and 1100 individuals. Data on the fish community had been collected in 2000 (Kroes and Riemersma 2001). Bream (Abramis brama L.) was the most abundant fish in biomass but this species is not herbivorous. Roach (Rutilus rutilus L.) and common carp (Cyprinus carpio L.) were the most abundant facultative herbivores. The density of roach was estimated at $22 \mathrm{~kg} / \mathrm{ha}$. Carp was estimated at $58 \mathrm{~kg} / \mathrm{ha}$, while rudd (Scardinius erythrophthalmus L.) density was low at $1.5 \mathrm{~kg} / \mathrm{ha}$ (Kroes and Riemersma 2001).

\section{Experimental design}

In early October 2003, prior to the arrival of Bewick's Swans, eight $12 \times 12 \mathrm{~m}$ blocks were established in the Babbelaar. We established two sets of four blocks that were $180 \mathrm{~m}$ apart. Within each set of blocks the distance between the centers of the blocks was $40 \mathrm{~m}$. Blocks were divided in four $6 \times 6 \mathrm{~m}$ plots, each receiving one of four treatments: a summer exclosure (S) preventing the consumption of aboveground parts by birds and large fish, a winter exclosure (W) protecting against tuberdigging waterfowl, a combination of both treatments
$(\mathrm{W}+\mathrm{S})$, and a control plot $(\mathrm{C})$, which was open yearround. Treatments were randomly assigned to the four plots within a block. For the summer exclosure a $6 \times 6 \mathrm{~m}$ cage was made, constructed of wooden poles and mesh wire (mesh size $5 \mathrm{~cm}$ ) and topped with bird netting (Appendix B). The cages had no measurable effect on the exploitation of the open plots by birds in summer: a comparison between tuber biomasses from a nearby transect and the control plot revealed a similar relation before and after exclosure establishment (37\% less biomass in 2003 and $36 \% \pm 18 \%$ [mean \pm SD] less biomass in 2004-2007 in the control plot than in the transect). The winter exclosure consisted of mesh wire placed on the sediment surface and kept in place with short bamboo sticks. Each year the cages were erected mid-March before tuber sprouting and removed at the end of September after senescence of aboveground material. The mesh wire was put in place immediately after cage removal and maintained until mid-March of the following calendar year. At the time of the first establishment of the plots, sediment cores were obtained to assess sediment particle size. The cores were sliced into segments with a length of $50 \mathrm{~mm}$. On the second and the fifth segment $(50-100 \mathrm{~mm}$ and $200-250 \mathrm{~mm}$ sediment depth, respectively) granulometric Malvern analyses were performed to obtain a measure of sediment particle sizes. Blocks $1-4$ had a slightly deeper water depth and were slightly more clayey than blocks 5-8 (Appendix A).

\section{Sampling}

All sampling was done inside an area of $4.5 \times 4.5 \mathrm{~m}$ within the $6 \times 6 \mathrm{~m}$ treatment plots in order to minimize edge effects. This area in turn was divided in 36 squares of $0.75 \times 0.75 \mathrm{~m}$. Aboveground material was sampled three times per growth season starting mid-June with five-week intervals. At each of these occasions three of the 36 squares were sampled. As nine samples were gathered each year, each sampling square was visited once and only once during the four-year experimental period. Assignment of sampling squares to sampling occasions was done randomly under the conditions that (a) on every sampling occasion one sample was gathered from each of two adjacent rows of sampling squares (rows 1-2, 3-4, and 5-6) and (b) no two bordering sampling squares were simultaneously assigned. Material was sampled by placing a core with a $50-\mathrm{cm}$ diameter over the vegetation. Plants were then harvested by hand at the sediment surface. Some samples were sorted to species level for other purposes, but all samples were dried at $60^{\circ} \mathrm{C}$ for $72 \mathrm{~h}$ and subsequently weighed. The biomass and number of sago pondweed tubers was assessed both at the end of September and in March by collecting 12 sediment cores with a $7-\mathrm{cm}$ diameter and a depth of $35 \mathrm{~cm}$ evenly spaced inside each treatment plot. The cores were sieved in the field at mesh size $3 \mathrm{~mm}$. Tubers were pooled for each plot, dried at $60^{\circ} \mathrm{C}$ for $72 \mathrm{~h}$, and weighed. 


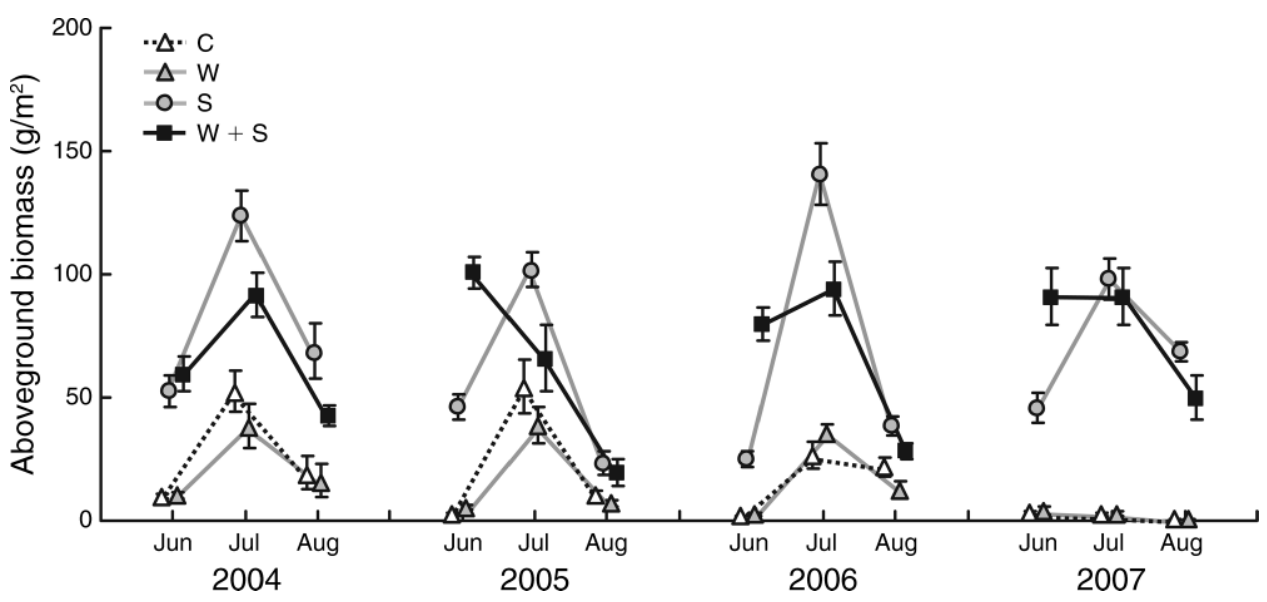

FIG. 2. Aboveground dry biomass of all aquatic vegetation (mean $\pm \mathrm{SE}$ ) as obtained at five-week intervals from June to August from three cores per plot with diameter $50 \mathrm{~cm}$ (based on back-transformed cube-root-transformed data, $\mathrm{g} / \mathrm{m}^{2}$ ) for each year and each treatment separately. The four treatments were: a summer exclosure (S) preventing the consumption of aboveground parts by birds and large fish, a winter exclosure (W) protecting against tuber-digging waterfowl, a combination of both treatments (W $+\mathrm{S}$ ), and a control plot $(\mathrm{C})$, which was open year-round.

\section{Statistical analysis}

The effect of exclosure treatments on total aboveground biomass was assessed in a linear mixed-effect model using the nlme package (Pinheiro and Bates 2000) in $\mathrm{R}$ ( $\mathrm{R}$ Development Core Team 2008). Biomass data were cube-root transformed to normalize the data. A Levene's test checked for the homogeneity of variances with data grouped for year, month, block, and treatment, yielding nonsignificant $P$ values in all cases. Winter treatment, summer treatment, and year were fixed factors. The factor month of sampling was nested within year. Block was a random factor within which summer treatment, winter treatment, and year were crossed. Significance of "block" was determined by elimination and comparison of the goodness of fit. A likelihood ratio test with one degree of freedom $(\alpha=$ 0.05 ) was performed to determine whether including block returned a better fit, as is appropriate for hierarchically nested models (Hilborn and Mangel 1997, Maindonald and Braun 2003). We estimated the number of relevant interactions by fitting the data with the mixed-effect model including a three-way interaction, a model with two-way interactions, and a model without interactions using maximum likelihood (ML) estimation. Analysis of variance was then applied to a model including block as a random factor and the relevant interaction level using a restricted maximum likelihood (REML) estimation method.

The effect of herbivory on tuber biomass in September and March, per capita survival over the winter, and per capita production over the summer were assessed using again linear mixed-effect models in R. We defined per capita survival as the number of tubers sampled in March divided by the number of tubers in September the autumn before. Tuber production was defined as the number of tubers encountered in September divided by tuber number in March of the preceding spring. Data were transformed by taking either the natural logarithm or the square root to meet normality assumptions. Homogeneity of variances was checked using Levene's test with data grouped for treatment and year. For the analysis on tuber mass in March and per capita survival over the winter, 2004 was excluded since no summer treatment had been applied at that time yet. Block was included as a random factor within which summer treatment, winter treatment, year, and the relevant level of interactions between these were nested. Significance of the factor block was assessed in the same way as described for aboveground biomass.

\section{RESULTS}

The summer exclosures had a strong positive effect on aboveground plant biomass with treatments $\mathrm{S}$ and $\mathrm{W}+$ $\mathrm{S}$ containing much more aboveground biomass than treatments $\mathrm{C}$ and $\mathrm{W}(P<0.001$; Fig. 2 , Table 1$)$. Plant biomass was different among years $(P<0.001)$, and the strength of the summer treatment effect also varied with year (significant summer $\times$ year interaction, $P<0.001$ ). In contrast, we found no effect of the winter exclosures on plant biomass independent of the factor year $(P=$ 0.958). An interaction between year and winter treatment was found, indicating that Bewick's Swan foraging in autumn did have an effect on aboveground biomass the next year but that this effect was positive or negative depending on year-to-year variation $(P=0.031)$. Summer treatment effects also varied with year (significant summer $\times$ year interaction, $P<0.001)$. In the absence of summer herbivores, Bewick's Swan herbivory caused a lag in vegetation development with reduced biomass in June from 2005 to 2007 in the summer only (S) treatments compared to the $\mathrm{W}+\mathrm{S}$ treatment. The advanced peak biomass in the $\mathrm{W}+\mathrm{S}$ treatment may thus 
TABLE 1. ANOVA results of the effects of the exclosure treatments on aboveground dry biomass of all aquatic vegetation in summer.

\begin{tabular}{lcrr}
\hline \hline \multicolumn{1}{c}{ Factor } & \multicolumn{1}{c}{ df } & \multicolumn{1}{c}{$F$} & \multicolumn{1}{c}{$P$} \\
\hline Winter & 1,1124 & 0.00 & 0.958 \\
Summer & 1,1124 & 1709.47 & $<\mathbf{0 . 0 0 1}$ \\
Year & 3,1124 & 50.72 & $<\mathbf{0 . 0 0 1}$ \\
Winter $\times$ summer & 1,1124 & 1.66 & 0.199 \\
Winter $\times$ year & 3,1124 & 2.97 & $\mathbf{0 . 0 3 1}$ \\
Summer $\times$ year & 3,1124 & 74.00 & $<\mathbf{0 . 0 0 1}$ \\
Month (year) & 8,1124 & 79.80 & $<\mathbf{0 . 0 0 1}$
\end{tabular}

Notes: Aboveground biomass was cube-root transformed. Block factor statistics are: $\Delta \mathrm{df}=1$, likelihood ratio $=0.24, P=$ 0.6219 . Significant $P$ values at $\alpha<0.05$ are indicated in boldface. Experiments were carried out in the "Babbelaar," a branch of the shallow lake Lauwersmeer in The Netherlands.

be a result of high tuber densities in spring due to absence of both summer and winter herbivores the year before (Fig. 2).

The biomass of tubers in September was affected negatively both by herbivory in summer $(P<0.001)$ and herbivory in winter $(P=0.009$; Fig. 3 , Table 2$)$. The effect of Bewick's Swans (i.e., winter herbivory) was, however, smaller than that of summer herbivory. The interaction between the summer treatment and year was significant $(P=0.005)$. Although the interaction between winter treatment and year was only marginally significant $(P=0.059)$, both the direction and magnitude of the
Bewick's Swan effect appeared to depend on the factor year. Block was significant with lower tuber biomass in the shallower, sandier plots (likelihood ratio $=14.21, P$ $<0.001$, data not shown). Tuber biomass in March, after the visit of Bewick's Swans and the winter season, was lower in the control and summer treatments than in the winter exclosed plots ( $\mathrm{W}$ and $\mathrm{W}+\mathrm{S})(P<0.001$; Fig. 4). A significant effect of the summer treatment could still be observed in March $(P<0.001)$. The factor year was not significant and exhibited reduced variability compared to the September data $(P=0.164)$. When evaluating a model with two-way interactions, one that was not favored by a likelihood ratio test, the interaction between summer and winter was marginally significant $\left(F_{1,79}=2.94, P=0.090\right.$; Fig. 4).

Both summer treatment and winter treatment had a significant effect on the per capita survival of tubers (Table 2), where the effect of the summer treatment was negative $(P<0.001)$ and that of the winter treatment was positive $(P<0.001)$ relative to the control (Fig. 5A). The per capita survival of tubers over the winter was hence lowest inside summer exclosures where initial tuber densities had been high, indicating that Bewick's Swans forage most intensively at these plots. Per capita survival was lower in the control plots than in the winter exclosed plots, due to consumption by swans. There was a significant interaction between year and winter treatment $(P=0.018)$, possibly due to variable tuber densities in
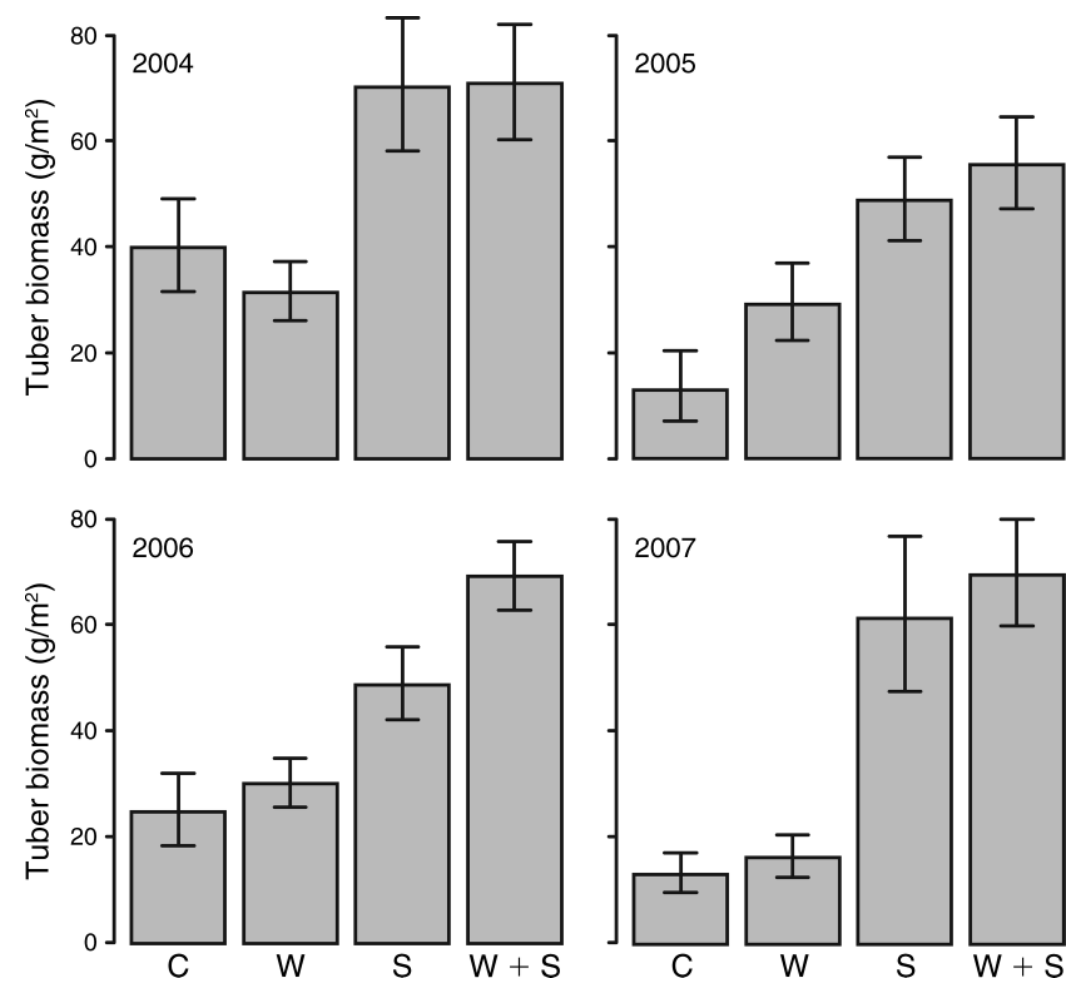

FIG. 3. Dry biomass of tubers (back-transformed, $\mathrm{g} / \mathrm{m}^{2}$; mean \pm SE) in September of 2004, 2005, 2006, and 2007 in the four treatments. In each plot 12 cores with diameter $7 \mathrm{~cm}$ were probed at least $35 \mathrm{~cm}$ in the sediment, sieved over $3 \mathrm{~mm}$, and dried. For an explanation of treatment abbreviations, see Fig. 2. 
TABLE 2. ANOVA results for tuber dry biomass in September and March and for per capita tuber survival ( $n$ March $/ n$ September, previous year) and per capita tuber production ( $n$ September $/ n$ March, same year).

\begin{tabular}{|c|c|c|c|c|c|c|c|c|c|c|c|c|}
\hline \multirow[b]{3}{*}{ Factor } & \multicolumn{6}{|c|}{ Tuber dry biomass } & \multirow{2}{*}{\multicolumn{3}{|c|}{$\begin{array}{c}\text { Survival } \\
\text { (per individual) }\end{array}$}} & \multirow{2}{*}{\multicolumn{3}{|c|}{$\begin{array}{c}\text { Production } \\
\text { (per individual) }\end{array}$}} \\
\hline & \multicolumn{3}{|c|}{ September } & \multicolumn{3}{|c|}{ March } & & & & & & \\
\hline & df & $F$ & $P$ & df & $F$ & $P$ & df & $F$ & $P$ & df & $F$ & $P$ \\
\hline Summer & 1,108 & 210.66 & $<\mathbf{0 . 0 0 1}$ & 1,84 & 22.92 & $<0.001$ & 1,79 & 27.88 & $<\mathbf{0 . 0 0 1}$ & 1,105 & 55.37 & $<\mathbf{0 . 0 0 1}$ \\
\hline Winter & 1,108 & 7.15 & 0.009 & 1,84 & 155.72 & $<0.001$ & 1,79 & 97.48 & $<0.001$ & 1,105 & 66.77 & $<0.001$ \\
\hline Year & 3,108 & 8.81 & $<\mathbf{0 . 0 0 1}$ & 2,84 & 1.84 & 0.164 & 2,79 & 1.92 & 0.153 & 3,105 & 15.87 & $<0.001$ \\
\hline Summer $\times$ winter & 1,108 & 0.04 & 0.841 & & & & 1,79 & 2.41 & 0.124 & 1,105 & 1.29 & 0.257 \\
\hline Summer $\times$ year & 3,108 & 4.58 & 0.005 & & & & 2,79 & 0.27 & 0.762 & 3,105 & 4.52 & 0.005 \\
\hline Winter $\times$ year & 3,108 & 2.56 & 0.059 & & & & 2,79 & 4.24 & 0.018 & 3,105 & 0.03 & 0.993 \\
\hline Summer $\times$ winter $\times$ year & & & & & & & & & & 3,105 & 2.43 & 0.069 \\
\hline
\end{tabular}

Notes: Tuber biomass was square-root-transformed. Survival and production were log-transformed. Block factor statistics are: tuber dry biomass, September, $\Delta \mathrm{df}=1$, likelihood ratio $=14.21, P<\mathbf{0 . 0 0 1}$; tuber dry biomass, March, $\Delta \mathrm{df}=1$, likelihood ratio $=$ 9.44, $P=\mathbf{0 . 0 0 2}$; survival, $\Delta \mathrm{df}=1$, likelihood ratio $=1.71, P=0.279$; production, $\Delta \mathrm{df}=1$, likelihood ratio $=4.16, P=\mathbf{0 . 0 4 1}$. Significant $P$ values at $\alpha<0.05$ are indicated in boldface.

autumn, which leads to variation in the fraction of tubers consumed by swans. The per capita production of tubers showed a pattern more or less opposite to survival, with all treatment main effects and year significant $(P<0.001$; Table 2, Fig. 5B). Production was highest inside the summer exclosed plots and lowest in the winter exclosed plots (Fig. 5B).

\section{DisCusSION}

The consumption of aboveground tissues by summer herbivores had tremendous effect on aboveground biomass of macrophytes in summer and the subsequent tuber bank in autumn in the Lauwersmeer. In autumn, Bewick's Swans strongly reduced tuber densities in winter-open plots, but in contrast, their impact on aboveground vegetation the following year was trivial. In some years, peak aboveground biomass appeared even higher inside the winter-open plots than in winterclosed plots, especially so in the summer-exclosed plots $(\mathrm{S}$ vs. $\mathrm{W}+\mathrm{S})$. Although the effect of Bewick's Swan herbivory on tuber biomass the year after was small, it varied marginally significantly with years. Apparently the success of plant growth over the summer season determines whether the effect of tuber predation tends towards positive (overcompensation) or negative (undercompensation). The disparity between compensatory responses to summer and winter herbivory confirms results from theoretical studies on sequential density dependence (Åström et al. 1996, Jonzén et al. 2002).

Strong compensation of pondweed to tuber herbivory as found in the Lauwersmeer is not uncommon, as comparable results were obtained for tuber predation by swans in ponds in the Canadian Rockies (LaMontagne et al. 2003) and in a different macrophyte species in North Carolina (Sponberg and Lodge 2005). Apparently, without grazing, higher tuber densities in spring result in retarded growth during the growing season in plant ramets through negative density dependence. In the reference situation of our study, vegetation in summer nonetheless appears to be top-down controlled, limited by aboveground herbivory rather than by resource limitation or tuber foraging. In effect, summer herbivores limit the availability of tubers to Bewick's Swans here representing a case of exploitative competition between seasonally tied herbivores. A reason is that consumption of green plant material by birds and fish implies the disappearance of the photosynthetic machinery. In addition, the removal of aboveground material increases wave exposure and thus mechanic stress to the remaining vegetation (Bouma et al. 2005). Also, $P$. pectinatus might succumb to competition from less consumed heterospecifics that may gain a foothold in the thinned pondweed beds (B. Hidding, B. A. Nolet, T. de Boer, P. P. de Vries, M. Klaassen, unpublished manuscript). And, if ducks and coots target the upper plant parts, which seems likely as diving is costly (de Leeuw 1996), the remaining plant tissues will face reduced light and reduced availability of carbon from the atmosphere (Portielje and Lijklema 1995). Interestingly, the combination of the notion that tolerance levels differ through sequential density dependencies and that activities of different herbivore species are restricted to separate seasons leads to contrasting competitive effects of herbivore species on one another. While herbivores of aboveground biomass in summer limit the availability of

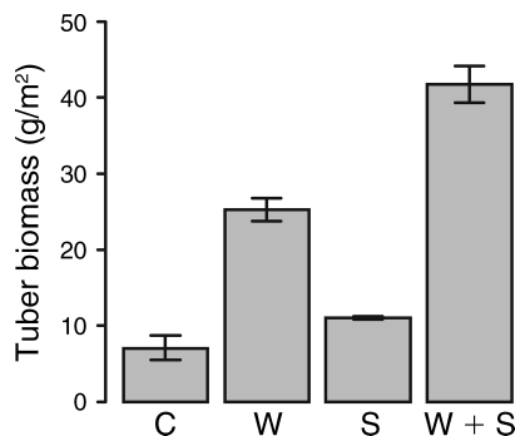

FIG. 4. Tuber dry biomass in March (back-transformed, $\mathrm{g} / \mathrm{m}^{2}$; mean $\pm \mathrm{SE}, n=3$ years) pooled over the years 2005-2007. In each plot 12 cores with diameter $7 \mathrm{~cm}$ were probed at least 35 $\mathrm{cm}$ in the sediment, sieved over $3 \mathrm{~mm}$, and dried. For an explanation of treatment abbreviations, see Fig. 2. 

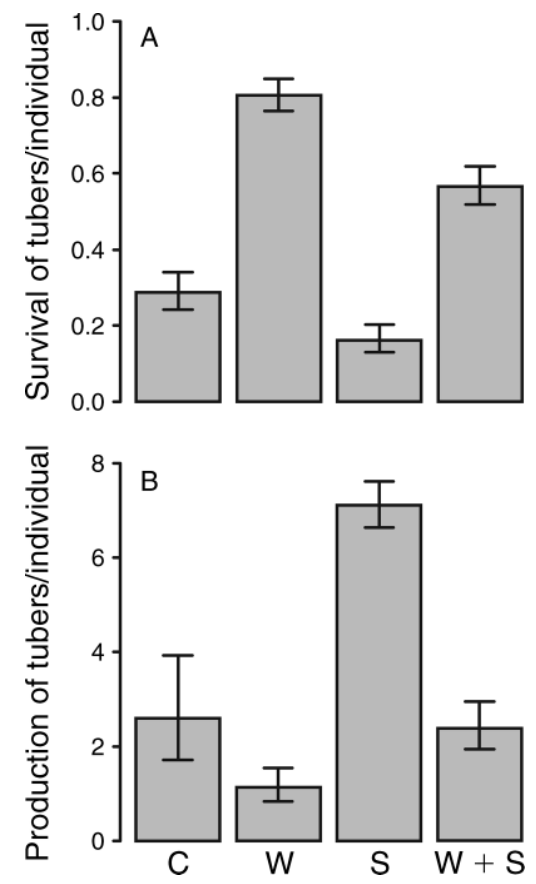

FIG. 5. (A) Per capita survival of tubers over the winter for the different treatments, back-transformed from log-transformed data ( $n$ March $/ n$ previous September). Error bars denote standard errors with $n=3$ winter seasons. (B) Per capita production of tubers from March to September, back-transformed from log-transformed data ( $n$ September $/ n$ March). Error bars denote standard errors with $n=4$ summer seasons. For an explanation of treatment abbreviations, see Fig. 2.

tubers to Bewick's Swans, the latter have no major consistent impact on food availability to herbivores in summer, despite heavy exploitation by both summer and winter herbivore assemblages.

The factor year strongly influenced plant growth and tuber production, but mostly so in the control plots. Notably so, the 2007 data reveal very low biomass in summer outside the summer exclosures $(\mathrm{W}, \mathrm{C})$. On the one hand, larger numbers of Mute Swans inhabited the lake in spring than the years before (Fig. 1), especially early in the growth season, but also unusually stormy conditions had occurred at the end of June and the beginning of July, in between the first and the second round of vegetation sampling. This circumstance may explain to some extent the low vegetation cover in 2007 outside compared to inside the exclosures. Fencing might limit wave action, but also dense vegetation itself decreases the vulnerability to waves (cf. Bouma et al. 2005). However, a comparison of aboveground biomass in summer open plots fully exposed to prevailing winds vs. summer open plots shielded from these winds by adjacent summer cages revealed no significant difference (analysis not shown) in vegetation cover in July 2007. Also, we consistently observed a sharp transition in aboveground biomass at the cage fences, suggesting a small wind effect. The role of Mute Swans in reducing sago pondweed cover may hence be an important subject of further study.

Mute Swans, ducks, and coots, present on the lake in large numbers throughout the growing season, are probably mostly responsible for the drastic reduction of aboveground biomass, but fish may play a role since large fishes were excluded as well by our cages. Of those herbivores carp was the most abundant in terms of fish biomass (Kroes and Riemersma 2001). Although carp has a low preference for $P$. pectinatus (Miller and Provenza 2007), it might negatively affect plant density when P. pectinatus is dominant (Miller and Crowl 2006). In addition, fish might play an important indirect role. Many species of fish are known to be molluscivorous. Snails, consuming mostly periphyton, may benefit aquatic plants as they are freed from competitors. Hence, the absence of large fish in the summer exclosures may promote macrophytes through the presence of snails (Brönmark et al. 1992, Jones et al. 2002).

Through grazing and possibly indirect interactions, waterfowl and fish in summer thus compete with Bewick's Swans in winter. Previous studies from disparate plant herbivore systems found similar asymmetries in the effect of exploitation of one herbivore on the other. Exploitative competition was suggested for hippopotamus (Hippopotamus amphibius L.) in Ugandan Queen Elizabeth Park, where it consumes large amounts of grass at night, therewith inhibiting exploitation of the same grasslands by day-feeders such as buffalo (Syncerus caffer Sparrman) (Lock 1972). Similarly, Fox (1996) reported Brent Geese (Branta bernicla (L.)) foraging on seagrass (Zostera spp.) shoots and rhizomes at low tide to be possibly inhibitory to Eurasian Wigeons (Anas penelope L.) that feed on aboveground shoots of seagrass at high tide. In yet another system that can only be appreciated with a microscope, herbivorous mites (Calacarus flagelliseta Fletchmann) and fungi (Oidium caricae F. Noack) were observed to compete for the same epidermal cells of papaya (Carica papaya L.) leaves, largely separated in time (Fournier et al. 2006). Whereas mites had a negative competitive effect on the fungi, mite densities were not reduced through fungal infestation of the leaves. These examples describe interspecific asymmetric competition in which one herbivore species has a strong negative effect on forage availability to the other through exploitative competition, but not obviously so the other way around. However, the mentioned studies refer to wholly different temporal timescales than our study. Hence, the mechanisms behind asymmetric exploitative competition in these systems are unlikely to hinge on density-dependent compensation as it does for herbivory on sago pondweed.

In conclusion, migratory Bewick's Swans may strongly reduce tuber biomass in the shallow lake Lauwersmeer while this heavy exploitation has no straightforward negative effect on aboveground biomass in the following 
summer. This observation indicates that sago pondweed is highly tolerant of tuber foraging. The relief from negative density dependence allows the plant to compensate through heightened per capita growth. Herbivory in summer by waterfowl, and possibly fish, however does have a negative effect on aboveground biomass and the subsequent tuber bank in autumn. Compensatory growth in this stage is limited possibly due to the loss of productive photosynthetic material, the increased susceptibility to wave exposure, and a lower availability of inorganic carbon. From the consumer viewpoint, in summer, herbivores exert a strong negative effect on the availability of tubers to Bewick's Swans through exploitative competition. On the other hand, Bewick's Swans seem mostly harmless to the food availability of fish and waterfowl inhabiting the Lauwersmeer in summer. Hence, sequential density dependence in a plant population may strongly influence the strength and symmetry of exploitative competition between seasonally tied herbivores.

\section{ACKNOWLEDGMENTS}

We thank Koos Swart for invaluable assistance in the field. We thank numerous students and colleagues who have helped collect data during the study period. We thank Staatsbosbeheer for kindly providing bird count data and for allowing us to work in the Lauwersmeer nature reserve. We thank Liesbeth Bakker, Thijs Vleugel, and two anonymous reviewers for reviewing an earlier version of this manuscript. This is NIOO publication number 4419 and publication 513 of the Centre for Wetland Ecology.

\section{Literature Cited}

Anderson, M. G., and J. B. Low. 1976. Use of sago pondweed by waterfowl on the Delta Marsh, Manitoba. Journal of Wildlife Management 40:233-242.

Arsenault, R., and N. Owen-Smith. 2002. Facilitation versus competition in grazing herbivore assemblages. Oikos 97:313318.

Åström, M., P. Lundberg, and S. Lundberg. 1996. Population dynamics with sequential density-dependencies. Oikos 75 : 174-181.

Barton, K. E. 2008. Phenotypic plasticity in seedling defense strategies: compensatory growth and chemical induction. Oikos 117:917-925.

Beekman, J. H., M. R. van Eerden, and S. Dirksen. 1991. Bewick's swans Cygnus columbianus bewickii utilising the changing resource of Potamogeton pectinatus during autumn in The Netherlands. Wildfowl Supplement 1:238-248.

Belsky, A. J. 1986. Does herbivory benefit plants? A review of the evidence. American Naturalist 127:870-892.

Boege, K. 2005. Influence of plant ontogeny on compensation to leaf damage. American Journal of Botany 92:1632-1640.

Bouma, T. J., M. B. de Vries, E. Low, G. Peralta, C. Tanczos, J. van de Koppel, and P. M. J. Herman. 2005. Trade-offs related to ecosystem engineering: a case study on stiffness of emerging macrophytes. Ecology 86:2187-2199.

Brönmark, C., S. P. Klosiewski, and R. A. Stein. 1992. Indirect effects of predation in a freshwater, benthic food chain. Ecology 73:1662-1674.

Cargill, S. M., and R. L. Jefferies. 1984. The effects of grazing by lesser snow geese on the vegetation of a sub-arctic saltmarsh. Journal of Applied Ecology 21:669-686.

de Leeuw, J. J. 1996. Diving costs as a component of daily energy budgets of aquatic birds and mammals: generalizing the inclusion of dive-recovery costs demonstrated in tufted ducks. Canadian Journal of Zoology 74:2131-2142.

Fournier, V., J. A. Rosenheim, J. Brodeur, J. M. Diez, and M. W. Johnson. 2006. Multiple plant exploiters on a shared host: testing for nonadditive effects on plant performance. Ecological Applications 16:2382-2398.

Fox, A. D. 1996. Zostera exploitation by brent geese and wigeon on the Exe estuary, southern England. Bird Study 43: $257-268$

Hangelbroek, H. H., N. J. Ouborg, L. Santamaría, and K. Schwenk. 2002. Clonal diversity and structure within a population of the pondweed Potamogeton pectinatus foraged by Bewick's swans. Molecular Ecology 11:2137-2150.

Harper, J. L., and J. White. 1974. The demography of plants. Annual Review of Ecology and Systematics 5:419-463.

Häsler, H., J. Senn, and P. J. Edwards. 2008. Light-dependent growth responses of young Abies alba to simulated ungulate browsing. Functional Ecology 22:48-57.

Hilborn, R., and M. Mangel. 1997. The ecological detective. Princeton University Press, Princeton, New Jersey, USA.

Hilt, S. 2006. Recovery of Potamogeton pectinatus L. stands in a shallow eutrophic lake under extreme grazing pressure. Hydrobiologia 570:95-99.

Hjältén, J., K. Danell, and L. Ericson. 1993. Effects of simulated herbivory and intraspecific competition on the compensatory abilities of birches. Ecology 74:1136-1142.

Inouye, D. W. 1982. The consequences of herbivory: a mixed blessing for Jurinea mollis (Asteraceae). Oikos 39:269-272.

Jones, J. I., J. O. Young, J. W. Eaton, and B. Moss. 2002. The influence of nutrient loading, dissolved inorganic carbon and higher trophic levels on the interaction between submerged plants and periphyton. Journal of Ecology 90:12-24.

Jonzén, N., B. A. Nolet, L. Santamaría, and M. G. E. Svensson. 2002. Seasonal herbivory and mortality compensation in a swan-pondweed system. Ecological Modelling 147:209-219.

Jupp, B. P., and D. H. N. Spence. 1977. Limitations of macrophytes in a eutrophic lake, Loch Leven. 2. Wave action, sediments and waterfowl grazing. Journal of Ecology 65:431-446.

Kokko, H., and J. Lindström. 1998. Seasonal density dependence, timing of mortality, and sustainable harvesting. Ecological Modelling 110:293-304.

Körner, S., and T. Dugdale. 2003. Is roach herbivory preventing re-colonization of submerged macrophytes in a shallow lake? Hydrobiologia 506:497-501.

Kot, M., and W. M. Schaffer. 1984. The effects of seasonality on discrete models of population growth. Theoretical Population Biology 26:340-360.

Kroes, M. J., and P. Riemersma. 2001. Visserijkundig onderzoek Lauwersmeer, winter en zomer. Organisatie ter verbetering van de binnenvisserij, Nieuwegein, The Netherlands.

LaMontagne, J. M., L. J. Jackson, and R. M. R. Barclay. 2003. Compensatory growth responses of Potamogeton pectinatus to foraging by migrating trumpeter swans in spring stop over areas. Aquatic Botany 76:235-244.

Lock, J. M. 1972. Effects of hippopotamus grazing on grasslands. Journal of Ecology 60:445-467.

Maindonald, J., and J. Braun. 2003. Data analysis and graphics using R.. Cambridge University Press, Cambridge, UK.

Maschinski, J., and T. G. Whitham. 1989. The continuum of plant responses to herbivory: the influence of plant association, nutrient availability, and timing. American Naturalist 134:1-19.

McNaughton, S. J. 1976. Serengeti migratory wildebeestfacilitation of energy flow by grazing. Science 191:92-94.

McNaughton, S. J. 1985. Ecology of a grazing ecosystem: the Serengeti. Ecological Monographs 55:259-294.

Miller, S. A., and T. A. Crowl. 2006. Effects of common carp (Cyprinus carpio) on macrophytes and invertebrate communities in a shallow lake. Freshwater Biology 51:85-94. 
Miller, S. A., and F. D. Provenza. 2007. Mechanisms of resistance of freshwater macrophytes to herbivory by invasive juvenile common carp. Freshwater Biology 52:39-49.

Nolet, B. A. 2004. Overcompensation and grazing optimisation in a swan-pondweed system? Freshwater Biology 49:13911399.

Nolet, B. A., R. M. Bevan, M. Klaassen, O. Langevoord, and Y. van der Heijden. 2002. Habitat switching by Bewick's swans: Maximization of average long-term energy gain? Journal of Animal Ecology 71:979-993.

Nolet, B. A., V. N. Fuld, and M. E. C. van Rijswijk. $2006 a$. Foraging costs and accessibility as determinants of giving-up densities in a swan-pondweed system. Oikos 112:353-362.

Nolet, B. A., A. Gyimesi, and R. H. G. Klaassen. 2006 b. Prediction of bird-day carrying capacity on a staging site: a test of depletion models. Journal of Animal Ecology 75:12851292.

Nolet, B. A., O. Langevoord, R. M. Bevan, K. R. Engelaar, M. Klaassen, R. J. W. Mulder, and S. van Dijk. 2001. Spatial variation in tuber depletion by swans explained by differences in net intake rates. Ecology 82:1655-1667.

Paige, K. N., and T. G. Whitham. 1987. Overcompensation in response to mammalian herbivory: the advantage of being eaten. American Naturalist 129:407-416.

Pinheiro, J. C., and D. M. Bates. 2000. Mixed-effects models in $\mathrm{S}$ and S-PLUS.. Springer Verlag, New York, New York, USA.

Portielje, R., and L. Lijklema. 1995. Carbon dioxide fluxes across the air-water interface and its impact on carbon availability in aquatic systems. Limnology and Oceanography 40:690-699.

Prejs, A. 1984. Herbivory by temperate freshwater fishes and its consequences. Environmental Biology of Fishes 10:281-296.

Prop, J., and M. R. van Eerden. 1981. Het voorkomen van trekvogels in het Lauwerszeegebied vanaf de afsluiting in 1969 tot en met 1978. Limosa 54:1-16.
R Development Core Team. 2008. R: a language and environment for statistical computing. R Foundation for Statistical Computing, Vienna, Austria.

Ratikainen, I. I., J. A. Gill, T. G. Gunnarsson, W. J. Sutherland, and H. Kokko. 2008. When density dependence is not instantaneous: theoretical developments and management implications. Ecology Letters 11:184-198.

Rosenthal, J. P., and P. M. Kotanen. 1994. Terrestrial plant tolerance to herbivory. Trends in Ecology and Evolution 9: 145-148.

Santamaría, L., and M. A. Rodríguez-Gironés. 2002. Hiding from swans: optimal burial depth of sago pondweed tubers foraged by Bewick's Swans. Journal of Ecology 90:303-315.

Schutten, J., J. Dainty, and A. J. Davy. 2005. Root anchorage and its significance for submerged plants in shallow lakes. Journal of Ecology 93:556-571.

Søndergaard, M., L. Bruun, T. Lauridsen, E. Jeppesen, and T. V. Madsen. 1996. The impact of grazing waterfowl on submerged macrophytes: in situ experiments in a shallow eutrophic lake. Aquatic Botany 53:73-84.

Sponberg, A. F., and D. M. Lodge. 2005. Seasonal belowground herbivory and a density refuge from waterfowl herbivory for Vallisneria americana. Ecology 86:2127-2134.

Strauss, S. Y., and A. A. Agrawal. 1999. The ecology and evolution of plant tolerance to herbivory. Trends in Ecology and Evolution 14:179-185.

van Wijk, R. J. 1988. Ecological studies on Potamogeton pectinatus L. 1. General characteristics, biomass production and life-cycles under field conditions. Aquatic Botany 31: 211-258.

Yoda, K., T. Kira, H. Ogawa, and K. Hozumi. 1963. Self thinning in overcrowded pure stands under cultivated and natural conditions. Journal of Biology (Osaka City University) 14:107-129.

\section{APPENDIX A}

General characteristics of the experimental blocks in the Lauwersmeer (Ecological Archives E090-131-A1).

\section{APPENDIX B}

Photograph of four of eight experimental blocks in the shallow lake Lauwersmeer shortly after summer exclosure establishment in March 2005 (Ecological Archives E090-131-A2). 